\title{
A preliminary study of the anti-inflammatory and anti-apoptotic effects of crocin against gastric ischemia-reperfusion injury in rats
}

\author{
Seyyed Ali Mard ${ }^{1,2,3,}$, Zahra Nikraftar, ${ }^{1,3}$, Yaghoob Farbood ${ }^{2,3}$, Esrafil Mansouri4,5 \\ ${ }^{1}$ Research Center for Infectious Diseases of Digestive System, Ahvaz Jundishapur University of Medical Sciences, Ahvaz, \\ Iran, ${ }^{2}$ Physiology Research Center, PRC, Ahvaz Jundishapur University of Medical Sciences, Ahvaz, Iran, ${ }^{3}$ Department of \\ Physiology, School of Medicine, Ahvaz Jundishapur University of Medical Sciences, Ahvaz, Iran, ${ }^{4}$ Department of Anatomic \\ sciences, School of Medicine, Ahvaz Jundishapur University of Medical Sciences, Ahvaz, Iran, ${ }^{5}$ Cellular and molecular \\ research center, Ahvaz Jundishapur University of Medical Sciences, Ahvaz, Iran
}

\begin{abstract}
The aim of the present study was to investigate the protective effect of crocin on gastric mucosal lesions caused by ischemia-reperfusion (I/R) injury in rats. Thirty-two male rats were randomly divided into sham, I/R, I/R + crocin pretreatment and crocin alone groups. To induce I/R lesions, the celiac artery was clamped for $30 \mathrm{~min}$, and the clamp was then removed to allow reperfusion for $3 \mathrm{~h}$. Crocin-pretreated rats received crocin $(15 \mathrm{mg} / \mathrm{kg}$, i.p.) $30 \mathrm{~min}$ prior to the induction of I/R injury. Samples of gastric mucosa were collected to quantify the protein expression of caspase-3, an apoptotic factor, and inducible nitric oxide synthase (iNOS), a pro-inflammatory protein, by Western blot. Pretreatment with crocin decreased the total area of gastric lesions and decreased the protein expression levels of caspase- 3 and iNOS induced by I/R injury. Our findings showed a protective effect of crocin in gastric mucosa against I/R injury. This effect of crocin was mainly mediated by reducing the protein expression of iNOS and caspase- 3 .
\end{abstract}

Uniterms: Crocin/protective effect. Gastric mucosal/lesions/ ischemia-reperfusion. Gastric lesions/ treatment/experimental study. Caspase-3. Inducible nitric oxide synthase.

\begin{abstract}
O objetivo do presente estudo foi investigar o efeito protetor da crocina em lesões da mucosa gástrica causadas por isquemia-reperfusão (I/R) em ratos. Trinta e dois ratos machos aleatoriamente divididos em grupos de ratos normais, operados como controle, I/R. I/R + pré-tratamento com crocina e crocina sozinha. Para induzir lesões I/R, a artéria celíaca foi grampeada durante 30 minutos e, em seguida, o grampo foi removido para permitir a reperfusão por $3 \mathrm{~h}$. Ratos com pré-tratamento com crocina receberam crocina (15 mg/kg, ip) 30 minutos antes da indução do dano I/R. Amostras de mucosa gástrica foram coletadas para qiuantificar a expressão da proteína da caspase-3, o fator apoptótico, e óxido nítrico sintase induzível (iNOS), uma proteína anti-inflamatória, pela técnica de Western Blot. O pré-tratamento com crocina diminuiu a área total de lesões gástricas e a expressão de níveis de caspase-3 e iNOS induzidas pelo dano I/R. Nossos resultados mostraram o efeito protetor da crocina na mucosa gástrica contra o dano I/R. Este efeito foi mediado, principalmente, por diminuição da expressão das proteínas iNOS e caspase-3.
\end{abstract}

Unitermos: Crocina/efeito protetor. Mucosa gástrica/lesão/isquemia-reperfusão. Lesões gástricas/ tratamento/estudo experimental. Caspase-3. Óxido nítrico sintase induzível.

\section{INTRODUCTION}

It is well established that reactive oxygen species (ROS) and reactive nitrogen species (RNS) are involved in the development of gastric ischemia-reperfusion (I/R) injury (Yoshikawa et al., 1989, Ishii et al., 2000). Also,

\footnotetext{
*Correspondence: Seyyed Ali Mard. Research Center for Infectious Diseases of Digestive System and Physiology Research Center (PRC) - Dept. of Physiology - School of Medicine - Ahvaz Jundishapur University of Medical Sciences. Ahvaz, Iran. E-mail: mard-sa@ajums.ac.ir; alimard77@gmail.com
}

the contribution of nitric oxide (NO) in I/R-induced gastric lesions has been documented (Wada et al., 1998). It has been shown that NO reacts with ROS and produces highly toxic substances such as peroxynitrite and singlet oxygen (Beckman et al., 1990, Noronha-Dutra et al., 1993). Naturally, NO is produced from L-arginine in mammalian tissues, catalyzed by three isoforms of NO synthase, two constitutive (eNOS and nNOS) and one inducible (iNOS) form. In oxidative stress, iNOS gene transcription and promoter activity are increased, regulating chromatin 
modification and leading to cellular injury (Huang et al., 2011, Yang et al., 2012).

Crocin is the most important and abundant antioxidant constituent of Crocus sativus stigma (Abdullaev, 1993). Beneficial effects of crocin have been reported on the nervous (Zheng et al., 2007), cardiac (Goyal et al., 2010) and renal (Hosseinzadeh et al., 2005) systems. Moreover, crocin has been shown to exert anti-inflammatory property by reducing edema in acetic acid-induced edema in the rat paw model (Hosseinzadeh, Younesi, 2002). Moreover, saffron and its active constituents, crocin and safranal, have been reported to attenuate the development of gastric mucosal lesions in different rat models of experimentally induced gastric ulcers, including water immersion restraint stress-, histamine-, non-steroidal anti-inflammatory drugs-, and pylorus-ligated-induced gastric lesions (Inoue et al., 2005, Al-mofleh et al., 2006, Xu et al., 2009). The mechanism of this protection was proposed to be mediated by a decrease in gastric non-protein sulfhydryl content (Al-mofleh et al., 2006).

NOS inhibitors such as L-NIO [ $N$-(1-iminoethyl)-Lornithine], L-NMA ( $N$-methyl-L-arginine), L-NIL [ $N$-(1iminoethyl)-L-lysine], and L-NNA ( $N$-nitro-L-arginine) have been shown to inhibit gene expression of iNOS, NO production, and caspase- 3 activity (Kiang, 2004). These results imply that iNOS activates apoptotic pathways, which in turn damage tissues. To our knowledge, there is no report about the anti-inflammatory and anti-apoptosis effects of crocin on gastric mucosa following I/R injury in the rat. Therefore, the aim of the present study was to evaluate the protective effect of crocin on gastric mucosal lesions induced by $\mathrm{I} / \mathrm{R}$ injury in the rat by evaluating the changes in the protein expression levels of active caspase-3, an apoptotic factor, and inducible nitric oxide synthase (iNOS), a pro-inflammatory protein, in gastric mucosa.

\section{MATERIAL AND METHODS}

\section{Material}

Chemicals: Crocin was purchased from Sigma. All antibodies were purchased from Abcam (USA).

\section{Animals}

Male Wistar rats weighing 150-200 g were purchased from the animal house of Ahvaz Jundishapur University of Medical Sciences. The animals were fed conventional diet and had free access to tap water. They were maintained under standard conditions of humidity, temperature $\left(22 \pm 2^{\circ} \mathrm{C}\right)$ and 12-h light/dark cycle. The animals were deprived of food but not water overnight before intervention. All experiments were carried out in accordance with the regulations set by the ethics committee of Ahvaz Jundishapur University of Medical Sciences (RDC9311).

\section{Methods}

\section{Animal grouping and experimental procedures}

The rats were randomly assigned to 4 groups $(\mathrm{n}=8)$ : sham, $\mathrm{I} / \mathrm{R}, \mathrm{I} / \mathrm{R}+$ crocin pretreatment and crocin alone groups. Gastric I/R injury was induced according to Wada et al., (1996). Briefly, under anesthesia with a mixture of ketamine and xylazine $(60+15 \mathrm{mg} / \mathrm{kg}$, i.p.), the rats underwent a midline laparotomy and the celiac artery was carefully isolated from its adjacent tissues. The celiac artery was then clamped by a ligature for 30 min to induce ischemia, and the ligature was removed to allow reperfusion for $3 \mathrm{~h}$. The I/R injury group received a single i.p. injection of vehicle (normal saline) 30 min prior to ischemia. Sham-operated rats underwent laparotomy without inducing I/R injury. To investigate the gastroprotective effect of crocin against mucosal damage induced by $I / R$ injury, one group of animals ( $/ / R+$ crocin pretreatment) received a single intraperitoneal injection of crocin at a dose of $15 \mathrm{mg} / \mathrm{kg}, 30 \mathrm{~min}$ prior to I/R injury. In a preliminary study, we evaluated the gastroprotective effect of crocin at 3 doses $(7.5,15$, and $30 \mathrm{mg} / \mathrm{kg})$ against I/R injury and showed that the optimal dose was $15 \mathrm{mg} /$ $\mathrm{kg}$ (Mard, Azad, 2014). Therefore, this dose of crocin was used in the present work. The crocin alone group received crocin $(15 \mathrm{mg} / \mathrm{kg}$, i.p. $)$ without any surgical operation. At the end of the experiment, animals were killed by cardiac puncture. To measure the gastric mucosal lesions, the stomach of animals was removed, opened along the greater curvature, rinsed with physiological saline and pinned out in ice-cold saline. To calculate the degree of gastric lesions, the total area of mucosal lesions were measured by Image $J$ software. The lesion area was expressed as the percentage of ulcerated area/the total area of the glandular stomach except for the fundus using the following formula: UI $(\%)=[$ Ulcerated area/total stomach area except fundus $] \times 100$ (Yonezawa et al., 2007). Immediately after taking a photograph of the stomach for measurement of the surface area of gastric lesions, samples of gastric mucosal tissue (50 mg each) including the lesion area and the surrounding ulcer margin were quickly excised, snapfrozen and stored in liquid nitrogen for molecular analysis.

\section{Microscopic evaluation of mucosal damage}

For histological evaluation, stomachs from all groups were fixed in 10\% formalin, dehydrated in a graded ethanol series, and embedded in paraffin. Afterwards, 
5 - $\mu \mathrm{m}$ sections of tissue were cut, stained with hematoxylin and eosin and assessed microscopically (Olympus IX50).

\section{Protein extraction}

The Tripure Isolation Reagent (Roche Diagnostics, Indianapolis, USA) was used to extract the total proteins from gastric mucosal tissue, according to the manufacturer's instructions. The protein pellets obtained from the gastric mucosal samples were dissolved in $1 \%$ SDS; protein concentration was determined by the Bradford assay, and mucosal proteins were analyzed by SDS-polyacrylamide gel electrophoresis (PAGE).

\section{Western blot analysis}

Mucosal proteins were separated by $10 \%$ SDSPAGE and transferred onto a nitrocellulose membrane. The membranes were blocked with 5\% non-fat dry milk dissolved in Tris-buffered saline with $0.1 \%$ Tween 20 (TBST, pH 7.6) for $6 \mathrm{~h}$ and then incubated overnight at $4{ }^{\circ} \mathrm{C}$ with anti-iNOS antibody (rabbit polyclonal, 1:400; Abcam [ab95441], USA), anti-caspase-3 antibody (rabbit polyclonal, 1:1000; Abcam [ab90437], USA) or anti-beta actin antibody (mouse monoclonal, 1:5000; Abcam [ab20272], USA). After 5 washes with TBST, membranes were incubated with a HRP-conjugated rabbit polyclonal anti-mouse IgG antibody; 1:7000) for $2 \mathrm{~h}$ at room temperature. Labeled proteins were detected using a chemiluminescence Western blotting system. The expression of the proteins studied was semiquantified by Image $\mathbf{J}$ analysis software and the values were normalized to $\beta$-actin.

\section{Statistical analysis}

Data are shown as mean \pm S.E.M. Statistical analysis was performed by one-way ANOVA and followed by a post hoc Turkey test. Significance was set at the $\mathrm{P}<0.05$ level.

\section{RESULTS}

\section{Effect of crocin pretreatment on gastric mucosal lesions induced by $I / R$ injury}

Microscopic examination showed gastric lesions with multiple erosions, exfoliation and necrosis of superficial cells, hemorrhage in the mucosal layer, marginal inflammation and neutrophil aggregation and severe alterations in the architecture of glandular parts of the gastric mucosa $3 \mathrm{~h}$ after ischemia. Pretreatment with crocin significantly attenuated the gastric lesions induced by I/R injury. No gastric damage was observed in the gastric mucosa of crocin alone and sham-operated rats (Figure 1). As shown in Figure 2, crocin pretreatment significantly decreased the total area of mucosal lesions as compared with the $\mathrm{I} / \mathrm{R}$ injury rats $(\mathrm{P}<0.001)$.

\section{Effect of crocin pretreatment on mucosal protein expressions of active caspase-3 and iNOS}

The level of iNOS protein expression in I/R + crocin pretreatment animals was significantly lower than in control I/R injury rats $(\mathrm{P}<0.01)$ (Figure $3 \mathrm{~A}$ ). Figure $3 \mathrm{~A}$ also shows that iNOS protein was not expressed in
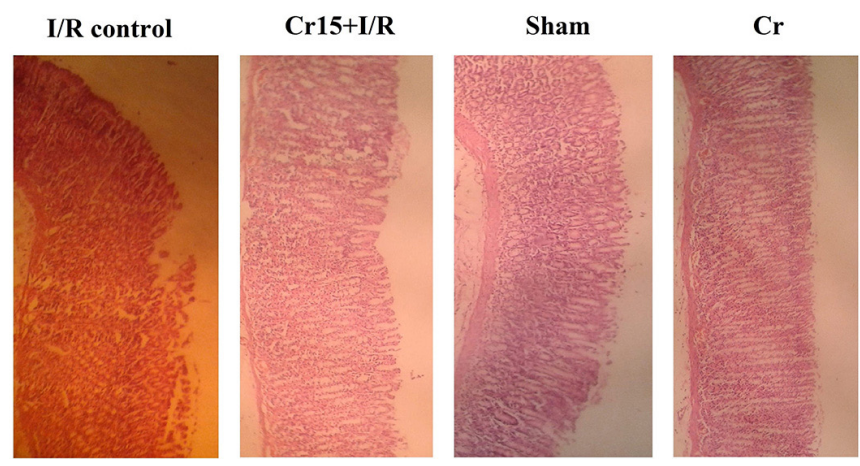

FIGURE 1 - Histological evaluation of the gastric mucosa. Representative gastric sections were obtained $3.5 \mathrm{~h}$ after I/R injury. Crocin alone $(\mathrm{Cr})$ and sham-operated groups depict no disruption in the surface epithelium. The I/R injury animals show multiple erosions (A-B), exfoliation and necrosis of superficial cells (arrow shows necrosis in Figure 1A), hemorrhage in the mucosal layer (arrows show hemorrhage in Figure 1B) and severe alterations in the architecture of glandular parts of the gastric mucosa. $\mathrm{Cr} 15+\mathrm{I} / \mathrm{R}$ : rats pretreated with crocin $(15 \mathrm{mg} /$ $\mathrm{kg} 30$ min before intervention) demonstrate mild disruption of the surface epithelium. All sections stained with hematoxylin and eosin; $\times 100$ magnification.

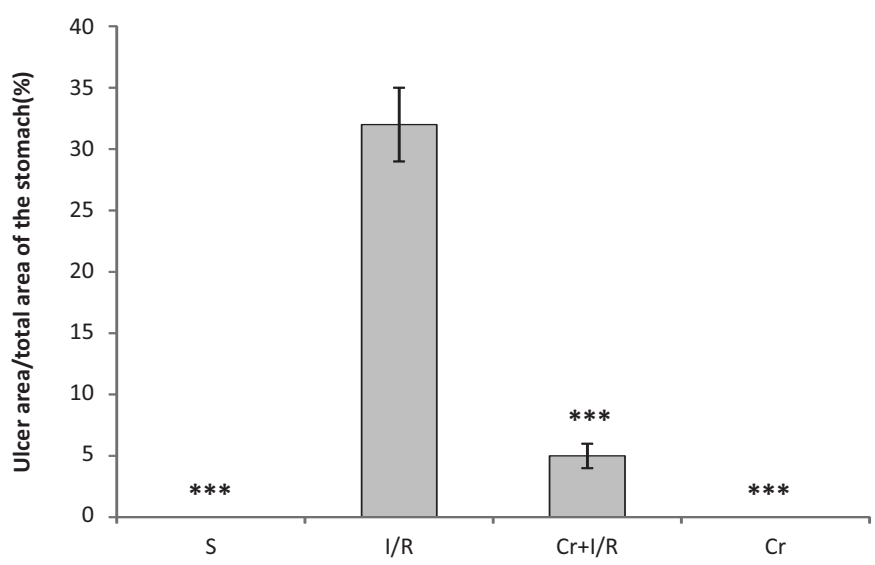

FIGURE 2 - The calculated ulcer index in S: sham-operated group, I/R: I/R injury animals, $\mathrm{Cr}+\mathrm{I} / \mathrm{R}$ : rats pretreated with crocin (15 mg/kg, i.p.) $30 \mathrm{~min}$ before intervention, $\mathrm{Cr}$ : crocin alone group (intact animals that received crocin at $15 \mathrm{mg} / \mathrm{kg}$, i.p.). $* * * \mathrm{P}<0.01$ relative to $\mathrm{I} / \mathrm{R}$ injury group. Data are expressed as mean \pm S.E.M. 
the crocin-alone and sham-operated groups. As shown in Figure 3B, 30 min gastric ischemia followed by $3 \mathrm{~h}$ reperfusion significantly increased the basal level of active caspase-3 expression as compared with the sham-operated animals $(\mathrm{P}<0.01)$. This level was significantly decreased by crocin pretreatment $(\mathrm{P}<0.01)$. There was no difference in the level of protein expression of caspase-3 between crocin-alone and sham-operated rats.

\section{DISCUSSION}

The results of this study showed that: (1) pretreatment with crocin decreased the total surface area of the acute gastric mucosal lesions induced by I/R; (2) the protein expression level of iNOS was lower in crocin-pretreated rats than in the I/R injury rats; and (3) the protein expression level of active caspase-3 was higher in the I/R injury rats than in $\mathrm{I} / \mathrm{R}+$ crocin-pretreated and sham-operated rats.

It has been shown that mRNA and protein expression of iNOS is upregulated following gastric I/R injury in mice and rats (Kobata et al., 2007; Yi et al., 2012). Consistent with these findings, the present study demonstrated that iNOS protein expression drastically increased after I/R injury in the rat stomach. The present results also showed that pretreatment with crocin significantly reduced mucosal lesions and the level of iNOS expression. Our findings showed that crocin, when administered alone, did not produce any change in the protein expression level of iNOS. This finding is in agreement with a previous study showing that crocin, when administered alone, caused no change in basal NO level in microglial cells but markedly protected these cells against LPS-induced inflammation (Nam et al., 2010). These findings suggest that the beneficial gastroprotective effect exerted by crocin is partly mediated by inhibition of iNOS protein expression.

To gain insight into other possible mechanisms that mediate the beneficial effects of crocin against I/R-induced gastric mucosal injury, a molecular marker for apoptosis (expression of active caspase-3) was also investigated. It has been shown that Yangsan flavonoid protected the heart against myocardial I/R injury through the downregulation of the expression of apoptosis genes including caspase-3 and adenine nucleotide translocator- 1 in rats (Zhang et al., 2014). Moreover, $N$-acetylcysteine has been reported to protect the gastric mucosa against I/R injury in rats by reducing mRNA expression of caspase-3 in gastric mucosa (Zhou et al., 2010). Therefore, these cited findings show that antioxidants protect the gastric mucosa against I/R injury through their anti-apoptotic activity. The results of the present study showed that 3.5 hours following I/R injury, the level of caspase-3 protein expression increased. As shown in Figure 3B, the

B
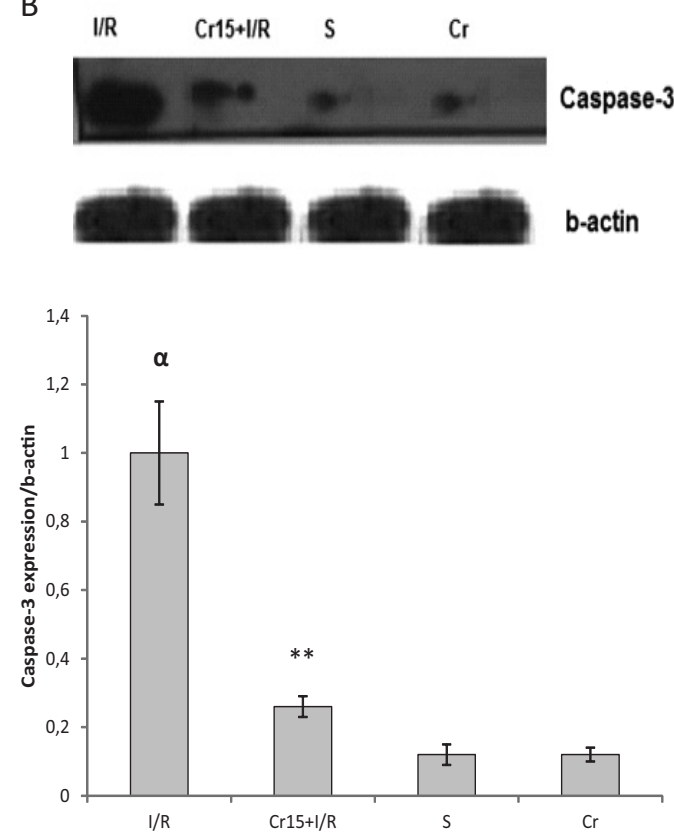

FIGURE 3 - Western blot analysis of iNOS (A) and caspase-3 (B) protein expression in the rat gastric mucosa following I/R injury. I/R: I/R injury animals, $\mathrm{Cr} 15+\mathrm{I} / \mathrm{R}$ : rats pretreated with crocin $(15 \mathrm{mg} / \mathrm{kg}$, i.p. $) 30 \mathrm{~min}$ before intervention, $\mathrm{S}$ : sham-operated group, $\mathrm{Cr}$ : crocin alone group (intact animals that received crocin at $15 \mathrm{mg} / \mathrm{kg}$, i.p.). Crocin pretreatment caused a significant decrease in iNOS and caspase- 3 protein expression. ${ }^{a} \mathrm{P}<0.001$ indicates a significant increase versus sham-operated and crocin alone groups; $* * \mathrm{P}<0.01$ and $* * * \mathrm{P}<0.01$ versus control I/R injury group. Data are expressed as mean $\pm \mathrm{SEM}$. The protein levels were normalized to $\beta$-actin. 
protein expression level of active caspase-3 significantly decreased with crocin pretreatment. Consistent with this finding, crocetin [another active constituent of saffron] has been shown to inhibit apoptosis at early stages of the brain injury following cerebral contusion, through up-regulation of Bcl-2 expression (Bie et al., 2011). Moreover, crocin has been reported to prevent retinal ischemia/reperfusioninduced apoptosis in retinal ganglion cells in rats (Qi et al., 2013). The protein expression level of caspase-3 with crocin alone was not different from sham-operated baseline values. Therefore, it can be concluded that another gastroprotective effect of crocin against $\mathrm{I} / \mathrm{R}$ injury is partly mediated by decreasing caspase- 3 protein expression.

In addition to crocin having a direct effect of on caspase-3 expression, it might have indirectly decreased caspase-3 expression by inhibiting iNOS expression in crocin-pretreated rats. As mentioned earlier, NOS inhibitors, in addition to down-regulating the gene expression of iNOS, inhibit caspase-3 activity (Kiang, 2004). Moreover, iNOS has been demonstrated to enhance intestinal apoptosis following I R injury in rats (Wu et al., 2002). Consistent with previous reports, the present findings showed that the basal levels of protein expression of caspase- 3 and iNOS increase in $\mathrm{I} / \mathrm{R}$ injury rats. Therefore, these results together suggest that the decrease in caspase- 3 protein expression in crocinpretreated rats may be secondary to the down-regulation of iNOS protein expression by crocin pretreatment.

\section{CONCLUSION}

In this in vivo study, an acute I/R-induced gastric lesion model was used to identify the role of iNOS and caspase- 3 in the mechanisms of the gastroprotective effect of crocin. The results showed that gastric I/R injury caused a significant increase in iNOS and caspase-3 protein expression, which was significantly attenuated by pretreatment with crocin.

\section{ACKNOWLEDGEMENT}

This study was part of the M.Sc. thesis of Ms. Zahra Nikraftar and financially supported by the Vice Chancellor of Research Affairs of Ahvaz Jundishapur University of Medical Sciences. This project has been registered under grant number RDC-9311. Dr. A. Leyva helped with English editing of the manuscript.

\section{REFERENCES}

ABDULLAEV, F. Biological effects of saffron. BioFactors, v.4, n.2, p. 83-86, 1993.
A1-MOFLEH, L.; ALHAIDER, A.; MOSSA, J.; A1SOHAIBANI, M.; QURESHI, S.; RAFATULLAH, S. Antigastric ulcer studies on'saffron'Crocus sativus L. in rats. Pakistan J. Biol. Sci., v.9, n.6, p.1009-1013, 2006.

BECKMAN, J.S.; BECKMAN, T.W.; CHEN, J.; MARSHALL, P.A.; FREEMAN, B.A. Apparent hydroxyl radical production by peroxynitrite: implications for endothelial injury from nitric oxide and superoxide. Proc. Natl. Acad. Sci. USA, v.87, n.4, p.1620-1624, 1990.

BIE, X.; CHEN, Y.; ZHENG, X.; DAI, H. The role of crocetin in protection following cerebral contusion and in the enhancement of angiogenesis in rats. Fitoterapia, v.82, n.7, p.997-1002, 2011.

GOYAL, S.N.; ARORA, S.; SHARMA, A.K.; JOSHI, S.; RAY, R.; BHATIA, J.; KUMARI, S.; ARYA, D.S. Preventive effect of crocin of Crocus sativus on hemodynamic, biochemical, histopathological and ultrastuctural alterations in isoproterenol-induced cardiotoxicity in rats. Phytomedicine, v.17, n.3, p. 227-232, 2010.

HOSSEINZADEH, H.; SADEGHNIA, H.R.; ZIAEE, T.; DANAEE, A. Protective effect of aqueous saffron extract (Crocus sativus L.) and crocin, its active constituent, on renal ischemia-reperfusion-induced oxidative damage in rats. J. Pharm. Pharm. Sci., v.8, n.3, p.387-393, 2005

HOSSEINAZADEH, H.; YOUNESI H.M. Antinociceptive and anti-inflammatory effects of Crocus sativus L. stigma and petal extracts in mice. BMC Pharmacol., v.2, n.1, p.7, 2002

HUANG, Y.J.; ZHANG, B.B.; MA, N.; MURATA, M.; TANG, A.Z.; HUANG, G.W. Nitrative and oxidative DNA damage as potential survival biomarkers for nasopharyngeal carcinoma. Med. Oncol., v.28, n.1, p. 377-384, 2011.

INOUE, E.; SHIMIZU, Y.; SHOJI, M.; TSUCHIDA, H.; SANO, Y.; ITO, C. Pharmacological properties of N-095, a drug containing red ginseng, polygala root, saffron, antelope horn and aloe wood. Am. J. Chin. Med., v.33, n.1, p. 49-60, 2005.

ISHII, M.; SHIMIZU, S.; NAWATA, S.; KIUCHI, Y.; YAMAMATO, T. Involvement of reactive oxygen species and nitric oxide in gastric ischemia-reperfusion injury in rats. Dig. Dis. Sci., v.45, n.1, p. 93-98, 2000. 
KIANG, J.G. Inducible heat shock protein $70 \mathrm{kD}$ and inducible nitric oxide synthase in hemorrhage/resuscitation-induced injury. Cell Res., v.14, n.6, p.450-459, 2004.

KOBATA, A.; KOTANI, T.; KOMATSU, Y.; AMAGASE, K.; KATO, S.; TAKEUCHI, K. Dual action of nitric oxide in the pathogenesis of ischemia/reperfusion-induced mucosal injury in mouse stomach. Digestion, v.75, n.4, p.188-197, 2007.

MARD, S.A.; Azad, S.M. Finding the optimal protective dose of crocin against gastric I/R injury in rats. In: IRANIAN CONGRESS OF PHYSIOLOGY AND PHARMACOLOGY, 21., Tabriz, 2013. Tabriz: Tabriz University of Medical Sciences, 2013.

NAM, K.N.; PARK, Y.M.; JUNG, H.J.; LEE, J.Y.; MIN, B.D.; PARK, S.U.; JUNG, W.S.; CHO, K.H.; PARK, J.H.; KANG, I.; HONG, J.W.; LEE, E.H. Anti-inflammatory effects of crocin and crocetin in rat brain microglial cells. Eur. J. Pharm., v. 648, n.1, p. 110-116, 2010.

NORONHA-DUTRA, A.A.; EPPERLEIN, M.M.; WOOLF, N. Reaction of nitric oxide with hydrogen peroxide to produce potentially cytotoxic singlet oxygen as a model for nitric oxide-mediated killing. FEBS Lett., v.321, n.1, p.59-62, 1993.

QI, Y.; CHEN, L.; ZHANG, L.; LIU, W.B.; CHEN, X.Y.; YANG, X.G. Crocin prevents retinal ischaemia/reperfusion injury-induced apoptosis in retinal ganglion cells through the PI3K/AKT signalling pathway. Exp. Eye Res., v.107, p. $44-51,2013$

WADA, K.; KAMISAKI, Y.; KITANO, M.; KISHIMITO, Y.; NAMAKAMOTO, K.; ITOH, T. A new gastric ulcer model induced by ischemia-reperfusion in the rat: role of leukocytes on ulceration in rat stomach. Life Sci., v.59, n.19, p.PL295-PL301, 1996.

WADA, K.; KAMISAKI, Y.; OHKURA, T.; KANDA, G.; NAKAMOTO, K.; KISHIMOTO, Y.; ASHIDA, K.; ITOH, $\mathrm{T}$. Direct measurement of nitric oxide release in gastric mucosa during ischemia-reperfusion in rats. Am. J. Physiol., v.274, n.3, Pt.1, p.G465-471, 1998.

WU B.; IWAKIRI, R.; TSUNADA, S.; UTSUMI, H.; KOJIMA, M.; FUJISE, T.; OOTANI, A.; Fujimoto, K. iNOS enhances rat intestinal apoptosis after ischemia-reperfusion. Free Radic. Biol. Med., v.33, n.5, p. 649-658, 2002.
XU, G.L.; LI G., MA, H.P.; ZHONG, H.; LIU, F.; AO, G.Z. Preventive effect of crocin in inflamed animals and in LPSchallenged RAW 264.7 cells. J. Agric. Food Chem., v.57, n.18, p.8325-8330, 2009.

YANG, S;R.; RAHMAN, I.,; TROSKO, J.E.; KANG, K.S. Oxidative stress-induced biomarkers for stem cell-based chemical screening. Prev. Med., v.54, p.S42-S49, 2012.

YI, L.; LINGSHAN, G.; CUI, Y.; XIAOXING, Y.; JUNNIAN, $\mathrm{Z}$. A preliminary study on protective effect of L-citrulline against ischemia-reperfusion induced gastric mucosal lesions in rat. Indian J. Pharmacol., v.44, n.1, p. 31-35, 2012.

YONEZAWA, D.; SEKIGUCHI, F.; MIYAMOTO, M.; TANIGUCHI, E.; HONJO, M.; MASUKO, T.; NISHIKAWA, H.; KAWABATA, A. A protective role of hydrogen sulfide against oxidative stress in rat gastric mucosal epithelium. Toxicology, v.241, n.1, p. 11-18, 2007.

YOSHIKAWA, T.; UEDA, S.; NAITO, Y.; TAKAHASHI, S.; OYAMADA, H.; MORITA, Y.; YONETA, T.; KONDO, $\mathrm{M}$. Role of oxygen-derived free radicals in gastric mucosal injury induced by ischemia or ischemia-reperfusion in rats. Free Radic. Res. Commun., v.7, n.3-6, p. 285-291,1989

ZHANG, X.; LIANG, X.; LIN, X.; ZHANG, S.; HUANG, Z.; CHEN, C.; GUO, Y.; XUAN, F.; XU, X.; HUANG, R. Mechanism of the Protective Effect of Yulangsan Flavonoid on Myocardial Ischemia/Reperfusion Injury in Rats. Cell Physiol. Biochem., v. 34, n.4, p. 1050-1062, 2014.

ZHENG, Y.Q.; LIU, J.X.; WANG, J.N.; XU, L. Effects of crocin on reperfusion-induced oxidative/nitrative injury to cerebral microvessels after global cerebral ischemia. Brain Res., v. 1138, p. 86-94, 2007

ZHOU, X.Y.; DU, D.S.; MA, X.B.; ZHANG, J.F. The protective mechanism of $\mathrm{N}$-acetylcysteine against ischemia/ reperfusion induced gastric injury in rats. Sheng Li Xue Bao., v.62, n.1, p. 69-72, 2010.

Received for publication on $26^{\text {th }}$ September 2014 Accepted for publication on $26^{\text {th }}$ June 2015 